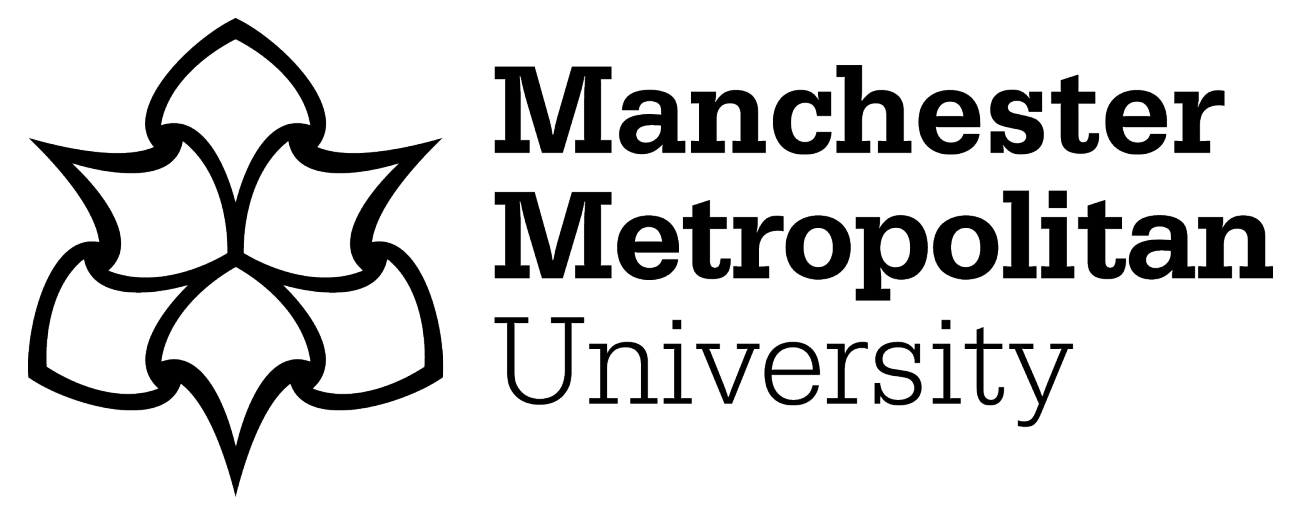

Alexis-Martin, Becky and Davies, Thom (2017) Towards nuclear geography: Zones, bodies, and communities. Geography Compass, 11 (9). ISSN 17498198

Downloaded from: https://e-space.mmu.ac.uk/623658/

Version: Accepted Version

Publisher: Wiley

DOI: https://doi.org/10.1111/gec3.12325

Please cite the published version 


\title{
Towards nuclear geography: Zones, bodies, and communities
}

\author{
Becky Alexis-Martin and Thom Davies
}

\begin{abstract}
:
Since the discovery of radioactivity in 1895, ionising radiation has become an increasingly prominent part of modern life. Here, we explore the diverse modes of interaction that occur between bodies and nuclear technology and point towards the scope for further research on nuclear geographies. We bring together different strands of this nascent discipline and, by doing so, highlight how nuclear technology interacts across a spectrum of geographic scales, communities, and bodies. Although nuclear geographies can be sensational and exceptionalising, such as the experiences of nuclear accident survivors and the creation of "exclusion zones," they can also be mundane, everyday and largely unrecognised, such as the production of nuclear energy and the life-giving nature of radioactive medicine. To frame our discussion, we take three cuts at nuclear geography, highlighting the importance of zones, bodies, and communities. By discussing this gamut of spaces and societies created through ionising radiation, we open the way for more research into the cross section of benefits, challenges, and social phenomena that arise, as we coexist with nuclear technology.
\end{abstract}

\section{INTRODUCTION: NUCLEAR MATTERS}

Far from there being "limited geographical research" (Castree, Rogers, \& Kitchin, 2013) into nuclear issues, nuclear geography has become an emerging field that encompasses a wide range of perspectives and approaches to the study of humans and ionising radiation. However, these varied themes are yet to be integrated. Here, we attempt to address this gap by exploring nuclear spaces and societies, from the exceptional to the everyday. We aim to provide an introduction to existing literature on nuclear geography and produce a critical review that points to potential new directions for future research. Though it is beyond the scope of this Compass article to uncover all aspects of nuclear geography, we hope here to provide some interesting insights into an emerging and exciting area of research. 
Nuclear technology is an important geographic issue. At its grandest scale, geographers often cite the detonation of nuclear bombs in the 1940s as demarcating the official start of the atomic "Anthropocene" by the presence of man-made isotopes in the soil and sediment of our planet (Lewis \& Maslin, 2015; Miller, 2016). From the perspective of imperceptible radiation, we are all geologically and biologically time stamped by this diffuse haze of fallout, which has irrevocably merged radiation with land and bodies. In some senses, we are all touched by nuclear technology, with ionising radiation having the capacity to connect disparate geographies through its vibrant and invisible materiality. In a more everyday sense, however, nuclear technology has far-reaching importance. Since the discovery of X-rays by Roentgen in 1895, nuclear technology has become a vital means of enhancing our lives, from therapeutic uses of radiation that improves the health of thousands of people each year to the increasing importance of nuclear energy to power the homes of millions of people around the world. Indeed, mounting concerns about climate change in our contemporary anthropocentric epoch has pushed a new agenda of energy resilience - and therefore nuclear energy - to the forefront once more (Bickerstaff, Lorenzoni, Pidgeon, Poortinga, \& Simmons,2008; Malin, 2015).

Whilst nuclear technology has proven to be versatile and useful to society, issues have also arisen surrounding defence, waste disposal, and disaster management that span vast spatial and temporal distances. These long range questions present many challenges for critical geographers. The multifaceted use of radiation means that "nuclear technology represents a heterogeneous area of social practices" (Irwin, 2013), and it is precisely this heterogeneity and its dynamic interrelation with society and space that nuclear geography is well placed to explore. It is impossible to view nuclear technology as a separate whole that exists apart from the social, political, and spatial relations that bring it to life (Hecht, 2012). It is therefore important to examine how nuclear technology interacts with space and place, inhabiting a wide range of geographic scales. We focus here on three critical sites of nuclear geography: the zone, the body, and the community. By exploring these important sites of nuclear technology, we demonstrate how nuclear issues inhabit spaces that can be simultaneously quotidian and spectacular, exceptional,and everyday.

We foreground this discussion by pinpointing the origins of nuclear research within the discipline of geography and contextualise the meaning of nuclear geography by reference to relevant historical and contemporary literature.Reaching beyond the confines of geographic scholarship, 
we also find critical intersections with anthropology, history,sociology, science and technology studies, and many other disciplines. By placing this work together with important scholarship by geographers on nuclear issues, we provide an introduction to nuclear geography.

\section{NASCENT NUCLEAR GEOGRAPHY}

Early works by geographers of nuclear issues contained unbridled optimism about the potential for nuclear technology to reinvigorate a European continent that had been ravaged by the Second World War (Hoffman, 1957; Jones, 1951).The potential mobility of nuclear energy, unrestrained by the location of natural resources, was an attractive proposition to geographers (Jones, 1951), who held the understanding that "power will be produced where needed at practically no additional cost" (Armand, 1955, cited in Hoffman, 1957). Possibilities seemed limitless, and a peaceful"geography of atomic energy" (Hoffman, 1957, p. 39) was foreseen, predicated on international scientific and political cooperation. Between 1957 and 1973 for example, "Project Ploughshare" used atomic energy as a tool for "geographical engineering" (Kirsch, 2000, p. 184), modifying the physical geography of landscapes through atomic excavation. Atthis time, the aim of developing abundant nuclear energy was widely accepted both by geographers and the public (Weart, 2012).

However, as both nuclear energy and nuclear defence flourished internationally, there was a change in the direction of geography scholarship towards a more subversive and critical study of the influence of ionising radiation upon society. The nuclear geography of the late Cold War focused upon worst-case scenarios and nuclear warfare, in anticipation of the social, economic, and health consequences of a mutually assured destruction that was thankfully never realised (Bunge, 1973; MacDonald, 2006; Openshaw \& Steadman, 1982, 1983). The scope of this era includes studies of the potential social impacts of hypothetical nuclear power plant sabotage and the long-term consequences of nuclear waste sites (Openshaw, 1986; Openshaw, Carver, \& Fernie, 1989; Openshaw, Forbes, Miller, \& Schmalz,1992). Geographers also critiqued the social impacts of nuclear deterrence (Wisner, 1986), critically disrupting geography's historical links to war and empire by creating new ways to discuss nuclear weapons within the context of peace (Cutter, Holcomb, \& Shatin, 1986; Solecki \& Cutter, 1987; Wisner, 1986). A more bombastic genre of geographical literature also emerged from these early forays into nuclear geography that explored the cultural hysteria of the Cold War through dystopian cartography. 
Bunge's Atlas of Nuclear War is a classic example of this and visually explored the (im)plausibility of human survival following mutually assured destruction (Figure 1; Bunge, 1989).

Created prior to the Comprehensive Nuclear Test Ban Treaty of 1996, Bunge's atlas visually represented data from 1970s spatial studies of nuclear attack to provoke thought and generate radical social change, rather than present an accurate perspective on nuclear risk. However, despite the belief that "issues of nuclear war and deterrence are inherently geographical" (Cutter, 1993, p. 132), academic radicals felt a lack of influence upon nuclear policy (Pasqualetti, 1986; White, 1988).

It is notable that these early endeavours into nuclear geography reflect the divisive nature of ionising radiation, with its capacity to both enhance life and bring it to a swift end. Nuclear technology produces a dialectical relationship between life and death, reflecting recent geographical scholarship on bio/necropolitics (Davies, Isakjee, \& Dhesi,2017; Mclntyre \& Nast, 2011). In what follows, we explore three key sites of nuclear geography: the zone, the body,and the community that are important areas of existing and future research. For each site, we demonstrate how nuclear technology inhabits spaces that both enhance and diminish life, in both spectacular and quotidian ways. Through this analysis, we are able to show how nuclear technology occupies both a biopolitical (Foucault, 1978)and necropolitical (Mbembé \& Meintjes, 2003) role in modern life.

\section{ZONES}

One of the more explicitly geographic aspects of nuclear technology is its close association with "zones." From exclusion zones and zones of nuclear industry to nuclear-free zones and enclosed spaces of technological experimentation or bunkers, zoning and nuclear technology are intrinsically linked. Nuclear spaces are unlike many others, as the invisible nature of ionising radiation means that there must be an active human designation and delineation of space in order for nuclear places to come into being. Creating nuclear spaces becomes a process, so that the nuclear environment is actively controlled, designed, and constructed (Kuchinskaya, 2012). Spaces of nuclear contamination,for example, occupy distinct geographies, but for these places to become noticeable to the human senses requires work (Hecht, 2012). A human 
influence is a prerequisite for making spaces "nuclear"; for instance, warning signs must be placed within the landscape; exclusion zones must be designed, mapped, and enforced; and technologies such as Geiger counters are needed in order to interpret, translate, or "see" the geographic spread of radiation. Without such active zoning of irradiated spaces, the "nuclear" aspect of these landscapes effectively disappears. In this sense,nuclear spaces are constructed socially and politically, and are subjected to a diverse array of different influences, that extend far beyond the ontological presence of radiation. Drawing the boundary between what is considered "nuclear"and what is not becomes a political technology, as much as a scientific one (Hecht, 2012). Nuclear zones do not just predicate around accidents but are also constructed around places of nuclear medicine, nuclear energy, and the nuclear military industrial complex. Within these day-to-day places of healthcare and industrial activity, zone design is present to protect both humans and state from risk.

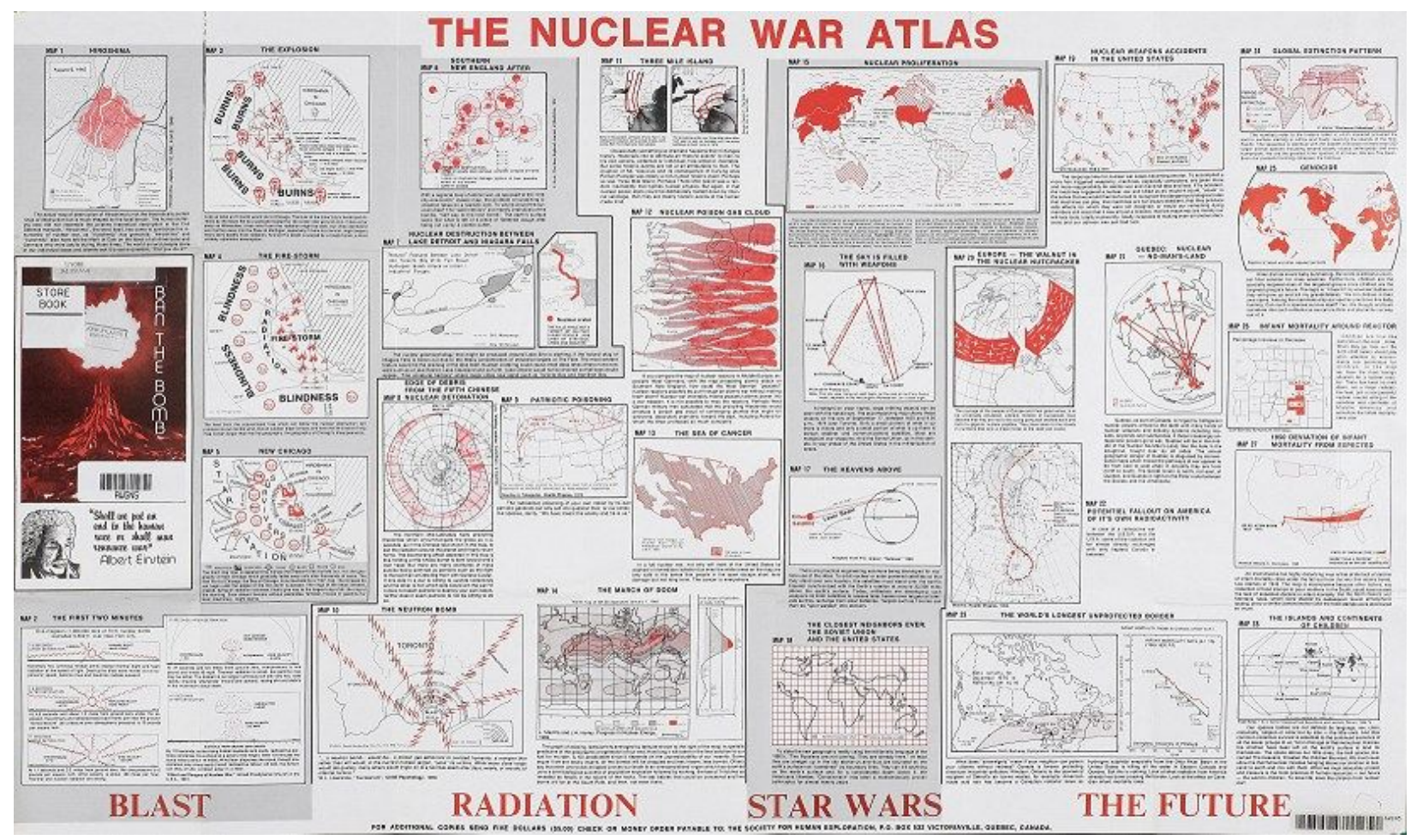

FIGURE 1: William Bunge's Atlas of Nuclear War (Bunge, 1989)

Perhaps the most spectacular examples of such nuclear zones are those that are constructed in the wake of nuclear disasters. Nuclear accidents demonstrate the complex intersections that occur between technology and society when both go wrong and have generated much empirical 
geographic research (Bickerstaff, 2012; Bickerstaff et al.,2008; Freudenburg \& Davidson, 2007; Irwin \& Wynne, 2003; Morris-Suzuki, 2014). Whilst nuclear accidents are infrequent, compared to other technological hazards, they are perceived by society to be very high impact events regardless of actual effects to health and the environment (Beck, 1992; Meyer, 1996; Venables, Pidgeon, Parkhill,Henwood, \& Simmons, 2012). The exclusion zones that are produced in the aftermath of such accidents become spatial symbols of ongoing technological failure and have parallels with "fallout zones," as discussed by Bunge (1989).Nuclear accident risk can therefore be described as existing in a state of constant becoming, and such sites of nuclear zones, waste storage, or defence are seen as places of latent risk to be mitigated (Beck, 1992; Davies, 2013;Freudenburg \& Davidson, 2007).

The Chernobyl and Fukushima "exclusion zones" in Ukraine and Japan are the most notable examples of postnuclear accident landscapes. Though there are other important nuclear accidents, including Windscale, UK(1957); Kyshtym, Russia (1957); and Three Mile Island, United States (1979), the scale of the 1986 Chernobyl disaster is especially striking. Fallout from the accident covered 150,000 km2 of Europe, affecting Belarus, Ukraine, and the Russian Federation in particular (UNSCEAR, 2000). Due to the enforcement of a 2,600 km2"Zone of Alienation" (Зонавідчуження Чорнобильської AEC) around the epicentre, about 350,000 people had to evacuate, and 2.1 million Ukrainians still inhabit land officially designated affected by the accident (Davies \& Polese, 2015). As Leshem and Pinkerton (2016) note, the Ukrainian use of the word "alienation" is particularly fitting in this example of a nuclear zone, as it gives "attention to less visible ruptures in the life fabric of individuals and communities medically and economically affected by the event" (p. 8). Communities are another important site of research into nuclear geography, as will be discussed later.

On a smaller scale to Chernobyl, the restricted region around the Fukushima accident in Japan showcases anothersite of the nuclear sublime (Shapiro, 2015). Around 210,000 individuals within a $20-\mathrm{km}$ radius of the epicentre were rapidly evacuated after the 2011 nuclear accident, and there remains uncertainty surrounding the anticipated physical, mental, and social impacts of the disaster (Hamada, Ogino, \& Fujimichi, 2012; Steinhauser, Brandl, \& Johnson,2014). Though this nuclear accident occurred 25 years after its Soviet predecessor, Fukushima was zoned in a similar way to Chernobyl, with the surrounding landscape being carved-up between 
"clean" and "unclean" territory,emphasising the crucial importance of zones within the governance of nuclear space (Davis \& Hayes-Conroy, 2017).

Both these exclusion zones have been extensively explored by geographers as sites of distinct biopolitical impor-tance (Davies, 2013; Davis \& Hayes-Conroy, 2017). The exclusionary "no man's lands" (Leshem \& Pinkerton, 2016)that are constructed after nuclear accidents are simultaneously spaces of enclosure, designed to contain radiation and exclude human life. In this sense, these exclusion zones are spaces of sovereign exception, where different rules and laws are enacted to protect the rest of society from invisible radiation (Davies \& Polese, 2015). Such exclusion zones have parallels with other polluted geographies, including "mitigation landscapes" (Little, 2012) or "sacrifice zones" (Lerner, 2010), where certain places (and people) are rendered disposable and "wasted" for the greater good(Bauman, 2013). The designation and zoning of places as contaminated and obsolete have direct consequences for inhabitants of these exceptional geographies. As Davis and Hayes-Conroy (2017, p. 1) found from their research in the Fukushima exclusion zone: "nuclear power as a social institution can require states to sacrifice the wellbeing of hundreds of thousands of their citizens."

Beyond these disaster geographies, nuclear bunkers are other notable zones of nuclear exceptionality. They are curious spaces that both preempt and embody risk (Klinke, 2015). Unlike exclusion zones, which are designated spaces of pollution, nuclear bunkers are designed to exclude radiation and protect its inhabitants. Recent scholarship by geographers has found that nuclear bunkers are spaces where sovereign power can either be entombed (Powell et al., 2016) or playfully disrupted (Ziauddin, 2016). Beyond the concrete materiality of the bunker, the progression and expansion of zones of industrial and military nuclear technology have also mirrored the spatial patterns and pathways of human development over the last 60 years (Merle-Lucotte, Heuer, Le Brun, \& Loiseaux, 2006). Nuclear technology is therefore globalised but also geographically enclosed, from uranium excavation to processing for energy and defence, to the economics of ownership and energy production, and nuclear waste management (Findlay, 2010). The zoning of the nuclear industrial complex also present challenges of unequal power relations: As Hecht (2012) has found from her research in Africa, exploitative patterns of uranium extraction, distribution, and exposure give the nuclear industry a curiously postcolonial spatiality. 
Within the context of weaponry, there are nine nuclear states that possess deterrence and create international zones of defence. Whilst many other non nuclear deterrence nations are protected by mutual defence treaties under organisations such as NATO, there are also places that have spurned the nuclear military industrial complex to create nuclear-free zones. These nations have become prominent spaces for protesting nuclear weapons. The earliest intentionally nuclear-free zone was uninhabited Antarctica, as a result of the 1961 Antarctic Treaty (Stokke \& Vidas, 1996). This treaty consisted of 14 articles that were designed to enforce peaceful international collaboration during the Cold War and persists to the present day (Peterson, 1988). Within the Treaty, Article 1 specified that Antarctica was to be used for peaceful purposes only; and Article 5 explicitly prohibited nuclear explosions and the disposal of radioactive waste (Stokke \& Vidas, 1996). The intention is that Antarctica will be preserved for scientific study for perpetuity. There are also intentionally nuclear-free zones that are populated, such as New Zealand, Austria, Nepal, and Mongolia. In the case of New Zealand, both nuclear energy and nuclear weapons have been prohibited, to create a nuclear-free zone (Clements, 2015; Mayell, 2004; Priestley, 2006). The decision against nuclear armament was initially undertaken by New Zealand as a member state of South Pacific Nuclear Free Zone Treaty that also included Australia, the Cook Islands, Fiji, Kiribati, Papua New Guinea, Tonga, and other South Pacific islands that was first signed during 1985 (Clements, 2015). New Zealand has taken this one step further, by including the prohibition of nuclear energy within national policy-as a nation that is rich in geothermal and other energy sources, this seems to be not just a product of nuclear activism but also pragmatism. In line with MacDonald's (2007, p. 592) call for outer space to become a "mainstream concern of critical geographers," it is also notable that celestial spaces-including the moon-have also been declared nuclear weapon-free zones, since the 1967 UN Outer Space Treaty.

In a less spectacular sense, nuclear-free zones also exist at the regional level. In the UK for example, 50 councils support the work of the "Nuclear Free Local Authorities" movement, where cities are encouraged to claim responsibility for disarmament, highlighting how their locality might present potential for empowerment and participation(Schregel, 2015). At a smaller scale still, De Socio (2010) points to campaigns for local "nuclear-free zones." For example, activists in Worcester, Massachusetts, consciously sought small scale zones of nuclear disarmament, as a means of challenging the wider geopolitical status quo "from below" (Miller, 1994). These peaceful uses of zonal geographies highlight more prosaic aspects of nuclear technology. The 
zone then, in terms of nuclear issues, retains the possibility of becoming a space of resistance, as well as enclosure and biopolitical exclusion.

Zones are of key importance to geographers researching nuclear issues, and they can be sites of exceptional nuclear governance, or new possibilities of peace. As the next section will demonstrate, it is also vital to uncover the more quotidian experiences of nuclear technology. Through this, we can see how the body is an important site of nuclear geography.

\section{BODIES}

Nuclear technology is entwined into our daily rhythms and activities in ways that often go unseen. This mundane spatiality of nuclear technology is another avenue through which human geographers are able to uncover and explore the role of high technology in our everyday lives. Whilst the previous section attended to the spectacular spaces created through rare but explosive nuclear errors, nuclear technology also inhabits more mundane spaces, from the hundreds of cities around the world that are powered through nuclear energy to the thousands of lives that are saved each year due to radioactive medicine, or the routine irradiation for fruits, vegetables, and meat to eradicate food-borne diseases. Indeed our everyday interaction with nuclear technology renders us unknowingly cyborg-like (Haraway,2013). The routine reach of nuclear technology into our everyday spaces is perhaps best demonstrated by the millions of domestic smoke alarms that protect us from fire, most of which contain the artificially produced radioisotope,americium-241. Discovered in 1945 during the Manhattan Project in the United States, this small facet of nuclear technology plays a key role in keeping our bodies safe as we go about our day-to-day lives.

An important yet prosaic way that many of us come into contact with nuclear technology is through healthcare. The geography of nuclear medicine is relatively unexplored yet is one of the most significant applications of nuclear technology and its interactions with the human body. Many will personally experience a nuclear medicine diagnosis or treatment during their lifetime (Early \& Sodee, 1995; Gnanasegaran, 2014). Therefore, nuclear medicine has an equally significant social and cultural influence, compared with accidents, energy, or defence. Like other kinds of health provision, an uneven "politics of cancer care" (Macdonald, 2016, 226) has emerged, meaning the availability of nuclear medicine is globally unequal. Whilst there are 
differences in general healthcare accessibility and treatment,there has been little exploration into the geographical differences in accessibility and experience of nuclear medicine(Kim, Farmer, \& Porter, 2013; Van Doorslaer et al., 1997). Therefore, nuclear medicine should form an important future component of future health and wellbeing geography as an indicator for diagnosis and treatment worldwide.

Nuclear imaging and medicine was originally a transatlantic endeavour, with X-ray imagery originating in Europe in the 1930s, whilst approaches towards nuclear pharmaceuticals for the treatment of health conditions were created in the United States from the 1950s onwards, often at military sites such as Oakridge Laboratory (Carlson, 1995). Nuclear medicine includes the broad spectrum diagnosis and treatment of disease by radioactive materials, from medical imaging to medications (Mettler \& Guiberteau, 2011; Trundle, 2013).

The nuclear geography of both the human body and of the hospital environment is both relevant as the personal experience of medicine has a significant influence upon patient outcome (Payne, Jarrett, Jeffs, \& Brown, 2001). During imaging, ionising radiation provides insights into the hidden geography and aesthetic of the body. There is a distinction between X-ray examination, where radiation is passed through the body to create an image, and the more intrusive process of nuclear medicine imaging, where radiopharmaceuticals are given internally and radiation is used as a tracer within the spaces of the body for either organ-based or whole body diagnosis (Mettler \& Guiberteau, 2011; Ziessman,O'Malley, \& Thrall, 2013). Whilst exposure to medical radiation is not considered to be a significant risk, there is a focus upon ensuring minimisation within "as low as reasonably practicable" (ALARP) guidelines (Ziessman et al.,2013). Radiotherapy is a common treatment-based nuclear medicine, used for autoimmune diseases and cancers including hyperthyroidism, thyroid cancers, lymphomas, and endocrine tumours and conditions (Gnanasegaran,2014). Linking the necropolitical experience of nuclear disaster or war with the biopolitical realities of health provision, radiotherapy has notable side effects with similar pathology to the symptoms of acute radiation syndrome. These include nausea, hair loss, sore skin, tiredness, and impacts upon libido and fertility (Gnanasegaran, 2014). The bodily geography of radiotherapy should be included within future study remits, as could the geographies of community support, diagnosis communication, and perception of treatment risks. 
The body and embodiment are vital aspects at the forefront of nuclear geography, and as such, we need to consider how humans are constituted by and with nature. This feeds into prominent work by geographers that highlight the important role of the body, corporeality, and embodiment within human geography (Hall, 2000; Silvey, 2017). As geographers have long argued, the body is more than "a site invaded by a disease" (Dorn \& Laws, 1994, p. 107) - or indeed by radiation but rather presents a space of negotiation and lived experience. Beyond healthcare, the figurative formulations of culture, nature, and subjectivity cannot be removed from the influence of toxic environments(Krupar, 2012; Schnabel, Breitwieser, \& Hawbaker, 2016). Spaces of the body, which are porous, renewing, and transforming (Choy, 2011), are therefore key sites for nuclear geographers, the body being as much a landscape and a repository for radiation as any other place (Brown, 2016). It is therefore possible to explore the bodily archive and to understand how the atomic Anthropocene is changing human bodies, the very essence of human geography, as the broader spatial consequences are echoed within us. Geographers have focused on the body as a key site of nuclear geography. For example, Cram (2015) discusses how planners of imaginary future nuclear accidents recast potential victims of radiation into quantifiable and neutral bodies - as bounded and statistically verifiable containers of radiation-who have specific exposure thresholds and easily manageable evacuation plans. As the next section will demonstrate, however, communities impacted by nuclear technology are heterogeneous and experience both exceptional and mundane encounters with radiation.

\section{THE NUCLEAR COMMUNITY}

Of critical importance to geographers researching nuclear spaces are the distinct societies that have arisen due to interaction with ionising radiation, from securitized nuclear defence towns to uranium mining communities and groups of nuclear accident survivors. Geographers have examined the experience of these communities within both local and global contexts. Originally, the term nuclear community arose from disaster risk reduction literature, after the 1986 Chernobyl nuclear accident (Lowrance, 1980; McKeown, 2003; Meyer, 1996). Its purpose was to distinguish between the "expert" and local community, whereby lay persons were deemed empty vessels into which the correct "facts"about nuclear power needed to be poured (Eden, 1998, Irwin, 2013). This secrecy and geographic distancing was inpart enshrined through the spatialized governance of nuclear technology itself and the geographically bounded way it was researched. It also propagated a "deficit" model of public understanding that was not always 
inclusive of local perspectives and knowledge (Eden, 1998; Irwin, 2013). The aspect of expertise was notably critiqued by Wynne(1996) who reflexively explored the lay-expert divide in his work in irradiated rural spaces. He described how sheep farmers on land contaminated by nuclear pollution were often ignored by scientists, despite farmer communities acquiring their own distinct and useful expertise about radiation.

Scientific "nuclear communities" were extant long before definition, hidden internationally in places of Cold War scientific nuclear research such as Mercury, Los Alamos, and Oakridge in the United States, Aldermaston in the UK,and Zelenogorsk in Russia. These "Plutopian" cities provided a secure environment and consistent employment for workers after the social and economic upheaval of World War II (Brown, 2013, p. 5). Neat, "clean," and affluent,the aspirational nature of these research communities " normalized and rendered invisible the massive nuclear installations hidden in plain sight" (Brown, 2013, p. 336). There was a quiet prestige associated with membership of the nuclear community at this time, due to its significant role in national protection during the Cold War nuclear arms race(Hunner, 2014, p. 216).

The contemporary interpretation of the nuclear community has shifted away from solely scientific expertise to include those who have experienced ionising radiation in other ways. This change is notable within communities of nuclear accidents and nuclear medicine, as the individual has greater access to information, more autonomy, and experts have realised the value of personal local and bodily expertise (Charles, Gafni, \& Whelan, 1999; Davies \& Polese, 2015). Interestingly, this development of a more inclusive and extensive nuclear community has been mirrored by greater public participation in public policy and citizen science (Chilvers, 2008; Irwin, 1995; Malin, 2015; Morris-Suzuki, 2014; Wynne, 1996). We now define a nuclear community as being any group that is associated with ionising radiation, which offers significant scope for exploration of different perspectives, demographics, and geographies (Blowers, 2016; Butler, Parkhill, \& Pidgeon, 2014; Litmanen, Kojo, \& Kari, 2010; Parkhill, Pidgeon, Henwood, Simmons, \& Venables, 2010; Venables et al., 2012; Whittaker, 2009). Within the context of nuclear geography, there is a significant back-catalogue of research that has not been considered despite its significance to nuclear communities.

Whilst nuclear technology plays a positive and important role in low-carbon energy generation and peacekeeping, occasions of historic mismanagement have created a human legacy of 
cultural and social impacts. The communities of Kazakhstan's Semipalatinsk nuclear weapons testing site and the British nuclear test veterans provide insights into the other side of the nuclear experience. The community of Semipalatinsk were living in a region of extensive USSR nuclear weapons testing from the 1950s to 1990s (Jumazhanova, Tursungozhinova, Belenko,Iskakova, \& Amanova, 2016; Stawkowski, 2016). The history of this place has led to community concern about the genetic and long-term risks of radiation exposure. Interestingly, members of this relatively isolated nuclear community claim to be "mutants" as a way of creating ownership of their marginalised situation, viewing themselves as biologically transformed, rather than disabled (Stawkowski, 2016). This provides insights into ways that affected communities can own their experiences. In contrast, the nuclear test veterans were the soldiers and scientists who tested the UK's nuclear weapons in Australasia and the South Pacific in the 1950s and 1960s (Alexis-Martin,2016). This community has had difficulties in gaining recognition of their status and identification of their specific needs, and individuals have also experienced contested and unmedicalised conditions that may or may not be due to exposure to ionising radiation (Sørensen, 2015; Trundle, 2013). Whilst the work of the nuclear test veterans has been memorialised, their individual experiences have not been shared. There has been little consideration of the long-term cultural and social impacts and intergenerational effects of perceptions of genetic damage within this community (Trundle, 2013).

A further example of a vibrant nuclear community can be found in the Chernobyl exclusion zone in north-central Ukraine. Within and beyond the $30-\mathrm{km}$ zone that surrounds the damaged reactor, members of a defiant local community returned to continue a bucolic existence, inside this fenced-off landscape (Davies \& Polese, 2015;Dobraszczyk, 2010). Significant work has recently been undertaken within the exclusion zone to discover residents' everyday relationships with risk and place, to understand how these communities "make uses of spaces that cannot be seen" by state due to perceptions of contamination (De Certeau 1984, cited in Davies, 2013). Nuclear spaces can create distinct identities. This can range from communities being stigmatised for their association with a polluted place (Mori, 2015; Davis \& Hayes-Conroy, 2017), or a sense of pride and resilience in their communal ability to survive in such an environmentally hostile situation (Bickerstaff, 2012; Davies, 2015; Stawkowski, 2016).What connects these disparate nuclear communities together is a shared experience of radiation. Future geo-graphical scholarship employing literature on the geographies of diasporas and 
identities (Christou \& Mavroudi,2016) may offer new in-roads into exploring these interconnections.

\section{DISCUSSION AND CONCLUSION}

Throughout this short review, we have highlighted how nuclear technology is an important and heterogeneous component of modern life. We have shown that nuclear technology inhabits spaces that are both exceptional and everyday, spectacular, and mundane. Geographers are in a unique position to tackle both the quotidian aspects of nuclear technology, as well as its more extreme ramifications across space and place. Nuclear technology, from energy generation to medicine, remains a burgeoning sector that is only likely to expand over the coming decades. This article has not aimed to give a definitive account of nuclear geography, but rather presents a first attempt at synthesising the diverse interactions of humans and ionising radiation, across space, place,and time.

In this paper, we have reviewed the historical work of geographers on nuclear issues, finding that a dialectic between positive and negative sides of nuclear technology has always been prominent in the discipline. We then took three cuts into nuclear geography, discussing how the zone, the body, and the community relate to nuclear geography.In doing so, we reveal multiple ways that we come into contact with ionising radiation across a range of geographic scales. This article is by no means an exhaustive account of the many ways that nuclear issues become geographic,rather we hope to inspire further engagement by human geographers interested in nuclear matters. Other avenues into nuclear geography have remained beyond the scope of this short review, including critical geographies of nuclear energy, waste mobilities, nuclear geopolitics, or more-than-human interactions with ionising radiation. Further, there exist many exciting theoretical approaches that geographers could use to explore nuclear issues, from assemblage theory (Garstin, 2014) to critical materiality (Bosworth, 2016), to phenomenological accounts of radiation, among many more. The door is surely ajar, then, for renewed focus on nuclear issues within human geography. Here, we hope to have given a snapshot of the potential avenues of exploration for future geographers interested in nuclear things. If other human geographers and allied social scientists are inspired to research the spatiotemporality of nuclear issues both small and large, then we have achieved our aims. 


\section{REFERENCES}

Alexis-Martin, B. (2016). Grapple slings and moonshine: Conversations with the men who tested atomic weapons on Christmas Island. Toxic News, European Research Council Toxic Expertise.

Armand, L. (1955). Some aspects of the European energy problem: Suggestions for collective action; report prepared for the OEEC. Organisation for European Economic Cooperation.

Bauman, Z. (2013). Wasted lives: Modernity and its outcasts. New Jersey: John Wiley \& Sons.

Beck, U. (1992). Risk society: Towards a new modernity (Vol. 17). Thousand Oaks: Sage.

Bickerstaff, K. (2012). "Because we've got history here": Nuclear waste, cooperative siting, and the relational geography of a complex issue. Environment and Planning A, 44(11), 2611-2628.

Bickerstaff, K., Lorenzoni, I., Pidgeon, N. F., Poortinga, W., \& Simmons, P. (2008). Reframing nuclear power in the UK energy debate: Nuclear power, climate change mitigation and radioactive waste. Public Understanding of Science,17(2), 145-169.

Blowers, A. (2016). The legacy of nuclear power. Oxford: Routledge.

Bosworth, K. (2016). Thinking permeable matter through feminist geophilosophy: Environmental knowledge controversy and the materiality of hydrogeologic processes. Environment and Planning D: Society and Space, 35(1), 21-37.

Brown, K. (2016). The Last Sink: The Human Body as the Ultimate Radioactive Storage Site. In C. Mauch (Ed.), Out of Sight,Out of Mind (pp. 41-47). München: The Politics and Culture of Waste, RCC Perspectives.

Brown, K. L. (2013). Plutopia: Nuclear families, atomic cities, and the great soviet and American plutonium disasters. USA: Oxford University Press.

Bunge, W. (1973). The geography of human survival. Annals of the Association of American Geographers, 63(3), 275-295.

Bunge, W. (1989). Nuclear war atlas. Oxford: Blackwell.

Butler, C., Parkhill, K., \& Pidgeon, N. (2014). From the material to the imagined: Public engagement with low carbon technol-ogies in a nuclear community. In P. Devine-Wright (Ed.), Renewable energy and the public: From NIMBY to participation(pp. 301). Oxford: Routledge. 
Carlson, S. (1995). A glance at the history of nuclear medicine. Acta Oncologica, 34(8), 1095-1102

Castree, N., Rogers, A., \& Kitchin, R. (2013). A dictionary of human geography. Oxford: Oxford University Press.

Charles, C., Gafni, A., \& Whelan, T. (1999). Decision-making in the physician-patient encounter: Revisiting the shared treatment decision-making model. Social Science and Medicine , 49(5), 651-661.

Chilvers, J. (2008). Environmental risk, uncertainty, and participation: Mapping an emergent epistemic community.Environment and Planning A, 40(12), 2990-3008.

Choy, T. (2011). Ecologies of comparison: An ethnography of endangerment in Hong Kong. Durham: Duke University Press.

Christou, A., \& Mavroudi, E. (2016). Dismantling diasporas: Rethinking the geographies of diasporic identity, connection and development. New York: Routledge.

Clements, K. (2015). Back from the brink: The creation of a nuclear-free New Zealand. Wellington: Bridget Williams Books.

Cram, S. (2015). Becoming Jane: The making and unmaking of Hanford's nuclear body. Environment and Planning D: Society and Space, 0263775815599317.

Cutter, S. L. (1993). Living with risk: The geography of technological hazards. London: Edward Arnold.

Cutter, S. L., Holcomb, H. B., \& Shatin, D. (1986). Spatial patterns of support for a nuclear weapons freeze. The Professional Geographer, 38(1), 42-52.

Davies, T. (2013). A visual geography of Chernobyl: Double exposure. International Labor and Working-Class History, 84,116-139.

Davies, T. (2015). Nuclear borders: Informally negotiating the Chernobyl exclusion zone. In Informal economies in post-socialist spaces (pp. 225-244). UK: Palgrave Macmillan.

Davies, T., \& Polese, A. (2015). Informality and survival in Ukraine's nuclear landscape: Living with the risks of Chernobyl.Journal of Eurasian Studies, 6(1), 34-45.

Davies, T., Isakjee, A., \& Dhesi, S. (2017). Violent Inaction: The Necropolitical Experience of Refugees in Europe. Antipode(early view). 
Davis, S., \& Hayes-Conroy, J. (2017). Invisible radiation reveals who we are as people:

Environmental complexity, gendered risk, and biopolitics after the Fukushima nuclear disaster. Social and Cultural Geography, 18,1-21.

De Socio, M. (2010). Geographers mobilize: A network-diffusion analysis of the campaign to free Ghazi-Walid Falah 1.Antipode, 42(2), 310-335.

Dobraszczyk, P. (2010). Petrified ruin: Chernobyl, Pripyat and the death of the city. City, 14(4), 370-389.

Dorn, M., \& Laws, C. (1994). Social theory, body politics and medical geography: Extending Kearns's invitation. The Professional Geographer, 46(1), 106-110.

Early, P. J., \& Sodee, D. B. (Eds.) (1995). Principles and practice of nuclear medicine. Maryland Heights: Mosby Incorporated.

Eden, S. (1998). Environmental issues: Knowledge, uncertainty and the environment. Progress in Human Geography, 22(3),425-532.

Findlay, T. (2010). Nuclear energy and global governance: Ensuring safety, security and non-proliferation. New York:Routledge.

Foucault, M. (1978). March 1979. Birth of Biopolitics: Lectures at the College De France, 79, 185-213.

Freudenburg, W. R., \& Davidson, D. J. (2007). Nuclear families and nuclear risks: The effects of gender, geography, and progeny on attitudes toward a nuclear waste facility. Rural Sociology, 72(2), 215-243.

Garstin, S. A. (2014). Assembling the atom: Development legacies, dialogue and the process of nuclear development in Pomerania, Poland. (Doctoral dissertation, University of Birmingham).

Gnanasegaran, G. (Ed.) (2014). Atlas of clinical nuclear medicine. Florida: CRC Press.

Hall, E. (2000). 'Blood, brain and bones ': Taking the body seriously in the geography of health and impairment. Area, 32(1),21-29.

Hamada, N., Ogino, H., \& Fujimichi, Y. (2012). Safety regulations of food and water implemented in the first year following the Fukushima nuclear accident. Journal of Radiation Research, 53(5), rrs032.

Haraway, D. (2013). Simians, cyborgs, and women: The reinvention of nature. New York: Routledge. 
Hecht, G. (2012). Being nuclear. Africans and the global uranium trade. Cambridge: Mass.

Hoffman, G. W. (1957). The role of nuclear power in Europe's future energy balance. Annals of the Association of American Geographers, 47(1), 15-40.

Hunner, J. (2014). Inventing Los Alamos: The growth of an atomic community. Norman: University of Oklahoma Press.

Irwin, A. (1995). Citizen science: A study of people, expertise and sustainable development. Oxford: Psychology Press.

Irwin, A. (2013). Sociology and the environment: A critical introduction to society, nature and knowledge. Cambridge: John Wiley \& Sons.

Irwin, A., \& Wynne, B. (2003). Misunderstanding science?: The public reconstruction of science and technology. Cambridge:Cambridge University Press.

Jones, S. B. (1951). The economic geography of atomic energy: A review article. Economic Geography, 27(3), 268-274.

Jumazhanova, G., Tursungozhinova, G., Belenko, O., Iskakova, M., \& Amanova, A. (2016). Ecological consciousness of a personality living in an ecologically unfavorable region. International Journal of Environmental and Science Education,11(7), 1469-1478.

Kim, J. Y., Farmer, P., \& Porter, M. E. (2013). Redefining global health-care delivery. The Lancet, 382(9897), 1060-1069.

Kirsch, S. (2000). Peaceful nuclear explosions and the geography of scientific authority. The Professional Geographer, 52(2),179-192.

Klinke, I. (2015). The bunker and the camp: Inside West Germany's nuclear tomb. Environment and Planning D: Society and Space, 33(1), 154-168.

Krupar, S. R. (2012). Transnatural ethics: Revisiting the nuclear cleanup of rocky flats, CO, through the queer ecology of nuclia waste. Cultural Geographies, 19(3), 303-327.

Kuchinskaya, O. (2012). Twice invisible: Formal representations of radiation danger. Social Studies of Science,0306312712465356.

Lerner, S. (2010). Sacrifice zones: the front lines of toxic chemical exposure in the United States. Cambridge: Mit Press. 
Leshem, N., \& Pinkerton, A. (2016). Re-inhabiting no-man's land: Genealogies, political life and critical agendas. Transactions of the Institute of British Geographers, 41(1), 41-53.

Lewis, S. L., \& Maslin, M. A. (2015). Defining the anthropocene. Nature, 519(7542), 171- 180.

Litmanen, T., Kojo, M., \& Kari, M. (2010). The rationality of acceptance in a nuclear community: Analysing residents' opinions on the expansion of the SNF repository in the municipality of Eurajoki, Finland. International Journal of Nuclear Governance, Economy and Ecology, 3(1), 42-58.

Little, P. C. (2012). Another angle on pollution experience: Toward an anthropology of the emotional ecology of risk mitigation. Ethos, 40(4), 431-452.

Lowrance, W. W. (1980). The nature of risk. In Societal risk assessment (pp. 5-17). New York: Springer.

Macdonald, A. (2016). Delivering breast cancer care in urban India: Heterotopia, hospital ethnography and voluntarism. Health and Place, 39, 226-232.

MacDonald, F. (2006). Geopolitics and 'the vision thing': Regarding Britain and America's first nuclear missile. Transactions of the Institute of British Geographers, 31(1), 53-71.

MacDonald, F. (2007). Anti -Astropolitik-Outer space and the orbit of geography. Progress in Human Geography, 31(5),592-615.

Malin, S. A. (2015). The price of nuclear power: Uranium communities and environmental justice. New Brunswick, New Jersey and London: Rutgers University Press.

Mayell, P. (2004). Beyond the 'outer crescent': The mackinder century in New Zealand geopolitics. The Geographical Journal,170(4), 368-376.

Mbembé, J. A., \& Meintjes, L. (2003). Necropolitics. Public culture, 15(1), 11-40.

Mclntyre, M., \& Nast, H. J. (2011). Bio (necro) polis: Marx, surplus populations, and the spatial dialectics of reproduction and"race" 1 . Antipode, 43(5), $1465-1488$.

McKeown, J. (2003). Decommissioning: Lessons to learn. Sharing experience and working together is important to allow the world nuclear community to respond to the challenge of restoring nuclear facilities safely, and cost effectively. IAEA Bulletin, 45(1), 24-20.

Merle-Lucotte, E., Heuer, D., Le Brun, C., \& Loiseaux, J. (2006). Scenarios for a worldwide deployment of nuclear power.International Journal of Nuclear Governance, Economy and Ecology, 1(2), 168-192. 
Mettler, F. A., \& Guiberteau, M. J. (2011). Essentials of Nuclear Medicine Imaging E-Book. Philadelphia: Elsevier Health Sciences.

Meyer, M. A. (1996). The nuclear community and the public: Cognitive and cultural influences on thinking about nuclear risk.Nuclear Safety, 37(2), 97-108.

Miller, B. (1994). Political empowerment, local-central state relations, and geographically shifting political opportunity structures. Political Geography, 13(5), 393-406.

Miller, B. (2016). Spaces of contention: Spatialities and social movements . Oxford: Routledge.

Mori, M. (2015). Geographies of precarious condition in the post-Fukushima. Dialogues in Human Geography, 5(1), 122-124.

Morris-Suzuki, T. (2014). Touching the grass: Science, uncertainty and everyday life from Chernobyl to Fukushima. Science Technology and Society, 19(3), 331-362.

Openshaw, S. (1986). Nuclear power: Siting and safety. Boston, MA: Routledge and Kegan Paul Ltd.

Openshaw, S., Carver, S., \& Fernie, J. (1989). Britain's nuclear waste: Siting and safety. London: Belhaven Press.

Openshaw, S., Forbes, G., Miller, E., \& Schmalz, R. (1992). The safety and siting of nuclear power plants when faced with terrorism and sabotage. In Natural and technological disasters: Causes, effects and preventive measures (pp. 455-468).Pennsylvania: The Pennsylvania Academy of Science.

Openshaw, S., \& Steadman, P. (1982). On the geography of a worst case nuclear attack on the population of Britain. Political Geography Quarterly, 1(3), 263-278.

Openshaw, S., \& Steadman, P. (1983). The geography of two hypothetical nuclear attacks on Britain. Area, 193-201.

Parkhill, K. A., Pidgeon, N. F., Henwood, K. L., Simmons, P., \& Venables, D. (2010). From the familiar to the extraordinary: Local residents' perceptions of risk when living with nuclear power in the UK. Transactions of the Institute of British Geographers,35(1), 39-58.

Pasqualetti, M. (1986). The dissemination of geographical findings on nuclear power.

Transactions of the Institute of British Geographers, 11(3), 326-336.

https://doi.org/10.2307/621793 
Payne, S., Jarrett, N., Jeffs, D., \& Brown, L. (2001). Implications of social isolation during cancer treatment: The implications of residence away from home during cancer treatment on patients' experiences: A comparative study. Health and Place, 7(4),273-282.

Peterson, M. J. (1988). Managing the frozen south: The creation and evolution of the Antarctic Treaty System (Vol. 20). California:University of California Press.

Powell, R. C., Klinke, I., Jazeel, T., Daley, P., Kamata, N. W., Heffernan, H., ... Phillips, R. (2016). Interventions in the political geographies of 'area'. Political Geography, (57), 94-104.

Priestley, R. (2006). The search for uranium in 'nuclear-free' New Zealand: Prospecting on the West Coast, 1940s to 1970s.New Zealand Geographer, 62(2), 121-134.

Schnabel, L., Breitwieser, L., \& Hawbaker, A. (2016). Subjectivity in Feminist Science and Technology Studies: Implications and Applications for Sociological Research. Sociology Compass, 10(4), 318-329.

Schregel, S. (2015). Nuclear war and the city: Perspectives on municipal interventions in defence (Great Britain, New Zealand,West Germany, USA, 1980-1985). Urban History, 42(04), 564-583.

Shapiro, N. (2015). Powerless Science? Science and Politics in a Toxic World. Soraya Boudia and Natalie Jas, New York: Berghahn Books; 292.

Silvey, R. (2017). Bodies and embodiment. The International Encyclopedia of Geography,1-7.

Solecki, W. D., \& Cutter, S. L. (1987). Living in the nuclear age: Teaching about nuclear war and peace. Journal of Geography,86(3), $114-120$.

Sørensen, B. R. (2015). Veterans' homecomings: Secrecy and postdeployment social becoming. Current Anthropology, 56(S12),S231-S240.

Stawkowski, M. E. (2016). "I am a radioactive mutant": Emergent biological subjectivities at Kazakhstan's Semipalatinsk nuclear test site. American Ethnologist, 43(1), 144-157.

Steinhauser, G., Brandl, A., \& Johnson, T. E. (2014). Comparison of the Chernobyl and Fukushima nuclear accidents: A review of the environmental impacts. Science of the Total Environment, 470, 800-817.

Stokke, O. S., \& Vidas, D. (1996). Governing the Antarctic: The effectiveness and legitimacy of the Antarctic Treaty System.Cambridge: Cambridge University Press. 
Trundle, C. (2013). Memorialising the veteran body: New Zealand nuclear test veterans and the search for military citizenship.War and the body: militarisation, practice and experience, 194-209.

UNSCEAR. (2000). Sources, effects and risks of ionizing radiation, 2000: Report to the general assembly. Retrieved from NewYork http://www.unscear.org/docs/reports/gareport.pdf Accessed March 21st 2017.

Van Doorslaer, E., Wagstaff, A., Bleichrodt, H., Calonge, S., Gerdtham, U. G., Gerfin, M., \& Leu, R. E. (1997). Income-relatedine qualities in health: Some international comparisons. Journal of Health Economics , 16(1), 93-112.

Venables, D., Pidgeon, N. F., Parkhill, K. A., Henwood, K. L., \& Simmons, P. (2012). Living with nuclear power: Sense of place,proximity, and risk perceptions in local host communities. Journal of Environmental Psychology, 32(4), 371-383.

Weart, S. R. (2012). The rise of nuclear fear. Massachusetts: Harvard University Press.White, G. F. (1988). Paths to risk analysis. Risk Analysis, 8(2), 171-175.

Whittaker, R. C. (2009). Fusing the nuclear community: Intercultural memory, Hiroshima 1945 and the Chronotopicdramaturgy of Marie Clements's burning vision. Theatre Research in Canada, 30(1-2), 129.

Wisner, B. (1986). Geography: War or peace studies? Antipode, 18(2), 212-217.

Wynne, B. (1996). May the sheep safely graze? A reflexive view of the expert-lay knowledge divide. In S. Lash, S. Bronislaw, \&B. Wynne (Eds.), Risk environment and modernity: Towards a new ecology. London: Sage.

Ziauddin, S. (2016). (De)territorializing the home. The nuclear bomb shelter as a malleable site of passage. Environment and Planning D: Society and Space,1-20.

Ziessman, H. A., O'Malley, J. P., \& Thrall, J. H. (2013). Nuclear medicine: The requisites. Philadelphia: Elsevier Health Sciences. 


\section{AUTHOR INFORMATION:}

Becky Alexis-Martin is a Nuclear Geographer and Research Fellow at the School of Human Geography, University of Southampton. Her research interests are focused upon atomic communities; the cultural and social effects of nuclear weapons, accidents, and industry; and the experiences of women and children. Becky has undertaken ethnographic and in-depth social research of the British nuclear test veterans and has previously written on the psychosocial effects to the women of Fukushima, Japan and Chernobyl, Ukraine. She is currently Principal Investigator of the Nuclear Families project, a national study that explores the intergenerational cultural and social impacts of nuclear weapons testing in the 1950s and 1960s. Becky's work has been previously published in journals including BELGEO and Environment and Society.

Thom Davies is a Nuclear Geographer and Research Fellow at the Department of Sociology, University of Warwick. Broadly, he is interested in toxic landscapes, risk perceptions, and geographies of exclusion. Thom has undertaken long-term ethnographic research with communities impacted by the Chernobyl nuclear disaster in Ukraine. In 2014, he received a JSPS scholarship at the University of Tokyo to conduct comparative qualitative research with marginalised groups impacted by the Fukushima nuclear accident. More recently, he undertook interdisciplinary research on the environmental health conditions in the Calais refugee camp in northern France.Thom works on an ERC-funded project Toxic Expertise, investigating the contested experiences of petrochemical pollution in "Cancer Alley," Louisiana. He holds a CEELBAS funded PhD from the School of Geography, Earth and Environmental Sciences, University of Birmingham. Thom's work has been published in journals including Anti-pode, Political Geography, and the Journal of Eurasian Studies.

\section{How to cite this article:}

Alexis-Martin B. and Davies T. (2017) Towards nuclear geography: Zones, bodies, and communities. Geography Compass. https://doi.org/10.1111/gec3.12325 